\title{
EVIDENCES OF ACTIVE FAULTING IN THRACE REGION (NORTH- EASTERN GREECE)
}

\author{
Th. Rondoyanni ${ }^{1}$, Ch. Georgiou ${ }^{1}$, D. Galanakis ${ }^{1}$, M. Kourouzidis ${ }^{2}$ \\ ${ }^{1}$ Institute of Geology and Mineral Exploration, Messoghion 70 str., Athens 11527, Greece. \\ ${ }^{2}$ Institute of Geodynamics, Ne tional Observatory of Athens, Thessio Athens, Greece
}

\begin{abstract}
Active oblique to strike-sli faults were identified in southern Thrace (northeastern Greece), on the basis of field observations, geological mapping, analysis of geometrical and dynamic characteristics of recent tectonic structtires as well as evaluation of their seismic potential.

The seismic activity refers mainly to strong earthquakes occurring under the sea, while a minor number of seismic epicenters have been registered on land. According to the historic and recent data, most seismic destructions in this region are due to the influence of the North Anatolian Fault and North Aegean Trough system.

The diachronic activity of several faults and the changes in the movement type from clearly normal to oblique-normal or strike-slip, have left clear signs on the existing polished fault planes. Among the numerous faults determined in Thrace, some of them can be characterized as active, according to their geological and morphotectonic characteristics. Taking in to account the faults length, the specific seismotectonic conditions prevailing over the Hellenic territory and the existed empirical relationships, the maximum displacement in case of seismic reactivation was estimated.
\end{abstract}

\section{INTRODUCTION - GEOLOGICAL SETTING}

The North Aegean Sea region has been the subject of many seismotectonic works the last two decades and the geodynamic pattern was concluded mainly on the basis of seismological and GPS derived data. All these works refer mainly to the North Anatolian Fault and North Aegean Trough system while neotectonic studies were focused mainly on central Macedonia and the Aegean islands (Pavlides et al., 1990; Foussos \& Lyssimachou, 1991). Eastern Macedonia and Thrace area does not present considerable local seismic activity and for this reason is considered as a rather stable region.

Although the most prominent structure is really the North Anatolian Fault system and its western expression and termination, Eastern Macedonia and Thrace, is also a well deformable region, since major and minor faults have keen found to affect the neogene and quaternary deposits. Even these faults present long periods cf reactivation, they should not be ignored as a probable source of seismic activity. Lessons taken from recent destructive earthquakes in Greece and other countries (Athens 1999, Kobe 1996 e.t. ..) occurring after a long period of quiescence, stress the necessity of future research in areas with moderate even low seismicity.

Refereeing to the geological structure. Thrace consists of formations attributed to the Rhodope mass and the circum-Rhodope belt as well as eruptive rocks, molassic formations and neogenequaternary deposits (figure 1). The Rhodope massif consists of metamorphic and eruptive rocks of a thickness about $24 \mathrm{~km}$. The schist-crystalline rocks of Rhodope (in the mountainous massif northwards of Komotini and Alexandroupolis towns) is distinguished in two basic units: the series of mica schists (consisted mainly of chlorite and partly mica schists to gneisses, whereas rarely amphibolites and marble lenses are intercalated) and the series of phyllites and marbles (consisted mainly of clayey phyllites, schists and quartzites, as well as of dolomitic marbles). The age of the aforementioned geological formations cannot be accurately determined due to the lack of stratigraphic indices. However, the deeper beds are attributed to Precambrian and Lower Paleozoic (Kockel \& Walther, 1965; Krorıberg et al., 1970). 
The circum-Rhodope zone in Thrace area consists of various sequences of rocks (phyllites, green schists and post-sediments of an old flysch, where bodies of basic eruptive rocks are intercalated) overthrusted on the Rhodope mass and continuing upwards with semi-metamorphic formations (Kopp, 1965; Maratos \& Andronopoulos, 1965; Papadopoulos, 1980)

The intense plutonism of the Rhodope is represented by granites, granodiorites, monzonites, quartz monzonites and diorites, of Eocene, Oligocene and Miocene age. A thick (about $2000 \mathrm{~m}$ ) molassic series of conglomerates, sandstones, marls and marly limestones with lignite horizons dates from Middle Eocene- Oligocene and probably up to the base of Miocene (Papadopoulos 1980, Katsikatsos 1992, Lalechos et al 1979).

Finally, the neogene and quaternary deposits that fill the great basins of Komotini and Alexandroupolis up to Evros river valley, are represented by:

- Miocene marine sediments of coastal facies consisting of white porous limestones, sandstones, marls and clays, as well as lacustrine deposits, consisting of alternations of sandstones, sands and sandy clays.

- Pliocene deposits: yellowish, sandy marls, loams and clays with layers of marly limestones.

- Pleistocene deposits: talus cones, scree and dilluvial deposits consisting of reddish clays and sands with lenses of non cohesive conglomerates.

- Alluvial deposits: clays, sandy clays, clayey sands and gravels extending over flat areas, marsh silts and torrent deposits.

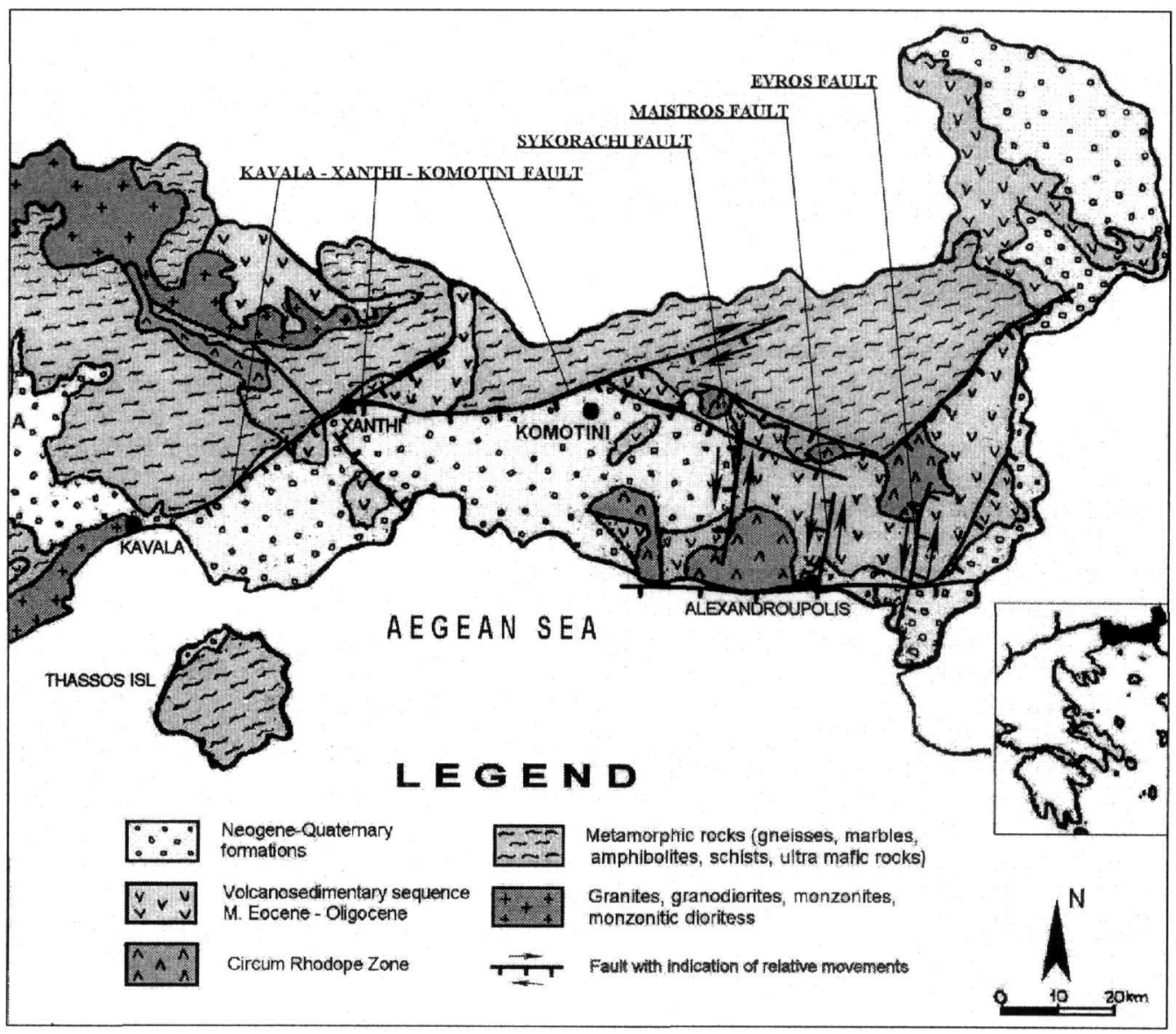

Figure 1. Simplified geological map of eastern Macedonia-Thrace (modified, from Katsikatsos, 1992). 


\section{NEOTECTONIC AND SEISMIC ACTIVITY}

The area extended to the east of Komotini town, as well as the wider region of the North Aegean, are characterized by the presence of great neogene-quaternary basins, which follow the ENE-WSW, WNW-ESE and N-S (with deviations from NNW-SSE to NNE-SSW) directions of the most important faults of Eastern Macedonia -Thrace.

The great fault zones determined through marine geophysical and geological surveys implemented over the North Aegean Sea region, during oil investigation projects, present also the same main directions. Furthermore, the morphological data of East Macedonia and Thrace, the development of the hydrographic network and the river basins, confirm the occurrence and influence of the aforementioned fault systems (Lalechos et al 1979).

Mercier et al. (1987) report that the neotectonic activity of the North Aegean region is defined by the influence of extensional tectonic stresses. The first extensional phase of WNW-ESE direction, took place during Upper Miocene and the second, of NE-SW direction, during Pliocene-Lower Pleistocene. From Middle Pleistocene to date, the stress field has a direction of about N-S. Karfakis (1991) after a detail structural analysis in the frame of the geological and mineral exploration of the eastern Rhodope, by the use of remote sensing techniques and field work, concluded that this area, between Priabonian and Middle(?) Miocene has developed through a simple shear deformation regime, while after middle Miocene the horizontal movements on the fault surfaces were gradually transformed into normal ones.

According to Koukouvelas and Aydin (2002) the northern Aegean basins and the faults which represent the diffused termination of the North Anatolian Fault system are consisted with the mechanical principles of strike-slip tectonics.

Kiratzi (2002) and Kiratzi and Louvari (2003), based on the focal mechanisms of shallow earthquakes in the Aegean region, determined in the region of Marmara a NNE-SSW $\sigma_{3}$ axis, which gradually changes to the west following a NNW-SSE direction.

Although the seismic activity is very strong in the North Aegean region, it refers mainly to strong earthquakes under the sea, while only a small number of seismic epicenters occurred in the area of the Eastern Macedonia and Thrace. The most known historic earthquakes manifested in the wider area are the following (Mougiaris 1994, Papazachos \& Papazachou 1997):

52 A.C. : The first known great earthquake reported in the area of Kavala, of $M=5.6$ magnitude, which destroyed Philippi.

1784 : The unique earthquake of $M=6,3$ magnitude that has struck the region of Komotini.

1829 : This earthquake of $M=7,3$ magnitude had epicenter the wider area of Drama which was totally destroyed and furthermore struck the wider region of eastern Macedonia, causing significant damages in Kavala, Xanthi, Eleftheroupolis and Andrianoupolis.

1867 : The epicenter of this earthquake was in the area of Drama, however damages and strong shocks were also reported from Thessaloniki to Dardanellia and Adrianoupolis.

Historic and recent earthquakes for the time period 52 to 2003 , with a magnitude $M>4$ illustrate on figure 2, where the North Anatolian Fault Zone (NAFZ) and its continuation to the North Aegean is clearly delineated.

\section{FAULT EVALUATION}

\subsection{Kavala-Xanthi-Komotini fault}

The most important neotectonic structure of the studied area is the fault zone of Kavala-XanthiKomotini, very well visible on satellite images and aerial photos, which terminates about in the Evros valley to the east (figure 3 ).

This fault zone, having a total downthrow of about $7 \mathrm{~km}$ (Lyberis, 1984), brings mainly into contact the metamorphic formations of Rhodope with the neogene-quaternary deposits. According to field observations, its geometric and dynamic characteristics (direction, dip and orientation of the tectonic slickensides) do not remain constant throughout its length. The slickenside groups observed on the polished fault planes indicate at least two movements, a dextral oblique-slip movement and a normal one. 


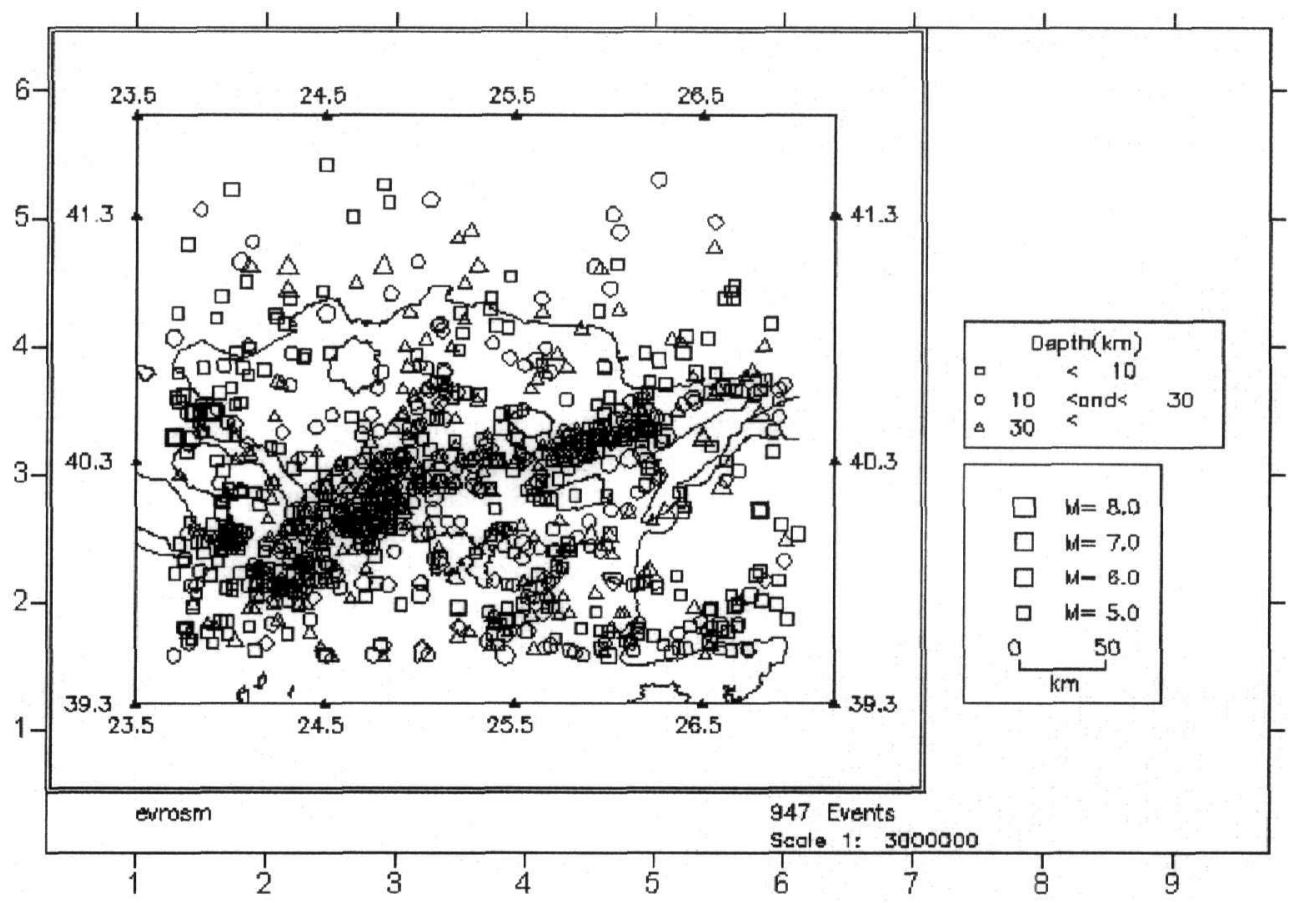

Figure 2. Earthquake epicenters in North Aegean region (time period 52-2003) with a magnitude $M>4$.

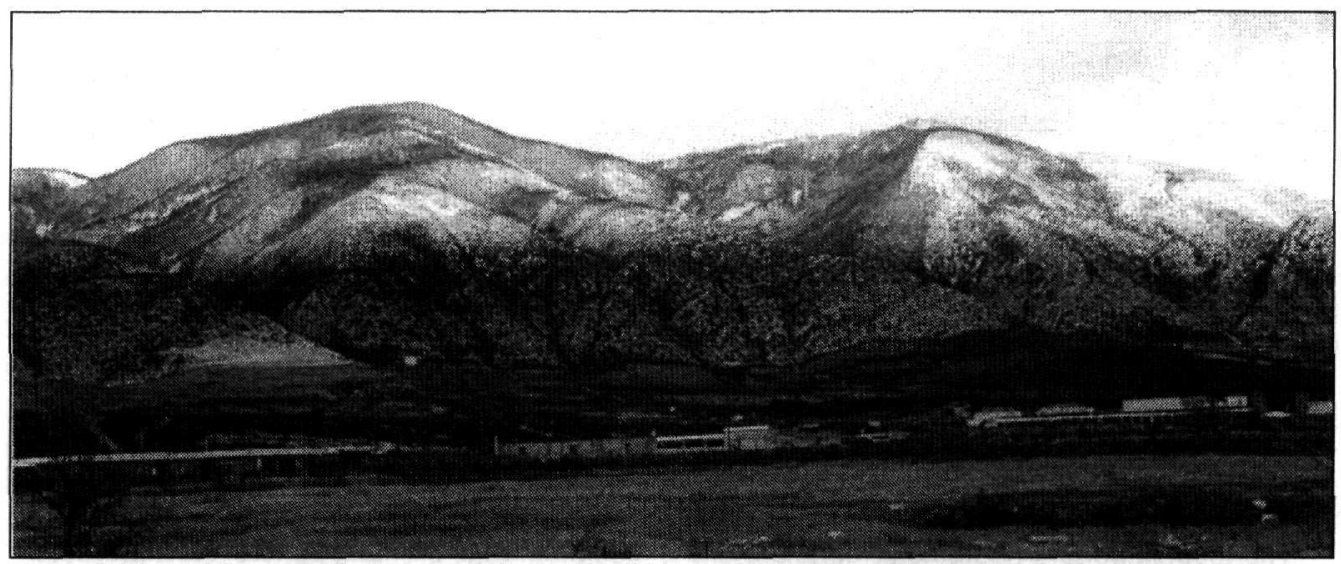

Figure 3. View of the major fault zone of Kavala-Xanthi-Komotini, between Rhodope massif and Xanthi basin.

Its total length is about $120 \mathrm{~km}$ and it is composed of at least three different segments which (from southwest to the east) is the Kavala - Xanthi (figure 4.), Xanthi - Komotini (figure 5) and Komotini - Aissimi ones. They present a NE-SW, E-W and WNW-ESE average direction respectively and a dip that ranges from about $35^{\circ}$ to $45^{\circ}$ (for the first segment) to $65-70^{\circ}$ (for the second one). The eastern Komotini - Aissimi segment is not represented in the field by a clear fault surface but is a rather complicated structure composed by a group of smaller parallel faults, that have formed the northeastern limit of Komotini basin. 


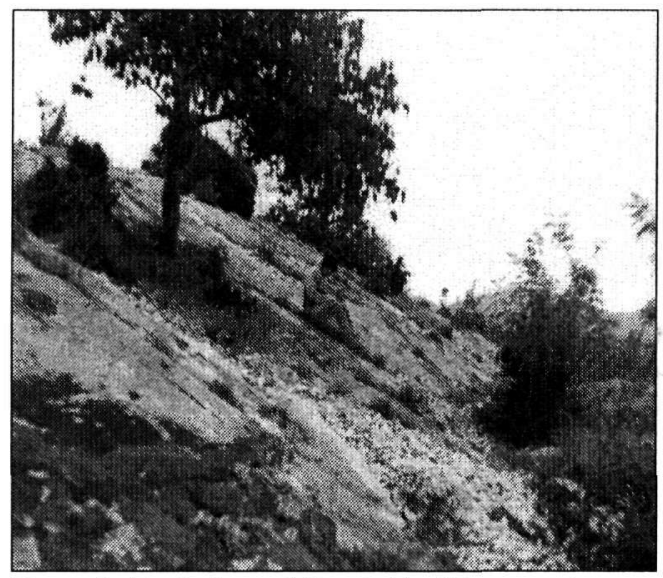

Figure 4. Fault plane of Kavala-Xanthi segment

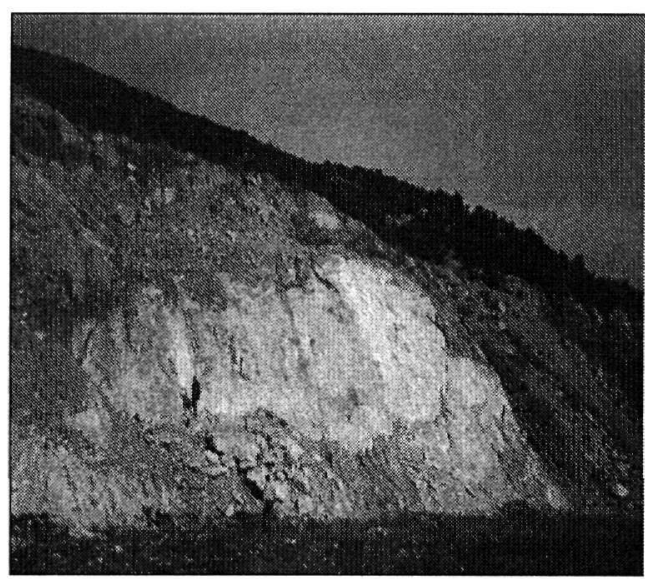

Figure 5. Fault plane of Xanthi-Komotini segment

The detailed study and evaluation of this fault is beyond the scope of this paper and the present work is focused on the N-S oriented faults and its activity potential, observed in Southern Thrace. The diachronic activity of these faults and the changes in the movement type (from clearly normal to oblique or strikeslip) are indicated in the slickenside groups observed on the existing polished fault planes.

They can be characterized as active and potentially active faults, according to their morphotectonic characteristics (the presence of polished fault surfaces, the alignment or displacement of streams) and especially the displacement of recent quaternary deposits. They are reactivated under NNE-SSW oriented $\sigma_{3}$ axis, as shown from their kinematic analysis by the use of Carey and Mercier (1987) program. These findings are in very good agreement with the results of focal mechanism analysis of regional shallow earthquakes (Kiratzi and Louvari (2003).

The identification and study of these faults, apart from its contribution to the consideration of the geodynamic pattern of North-eastern Greece, has in particular an important contribution in the evaluation of the seismic hazard of the region.

From a number of subparallel faults presenting similar characteristics, the most important leftlateral ones are the following:

\subsection{Sykorachi fault}

Sykorachi fault (figures 6 and 7) brings into contact the crystalline basement (schists and marbles) with paleocene-eocene volcanic rocks (rhyolites, dacites, andesites and pyroclastics) and the overlying neogene-quaternary deposits. It dips to the west constituting the eastern boundary of Komotini basin. This fault, to the south of Sykorachi village, is separated in a second smaller branch, influencing mainly the volcanic materials.

Sykorachi fault, having a total length of about $21 \mathrm{~km}$, influences the active hydrographic network and separates a region of intense erosion to the east from a region of low to moderate erosion to the side of its hanging wall.

The fault surface has a clear expression with a visible height of about $3 \mathrm{~m}$. Two different groups of striations, corresponding to normal and left-lateral strike-slip movement are observer on the polished fault surface.

\subsection{Maistros fault}

This is an oblique-slip fault forming the little, almost rectilinear, valley of Maistros river, very well visible on satellite images and aerial photos. It affects the eocene sediments as well as the quaternary fluvioterrestrial deposits. The later are mainly torrential conglomerates, sands and red loams forming an important terrace on the footwall side of Maistros fault. It is considered as an active fault and has a total length of about $9 \mathrm{~km}$. 


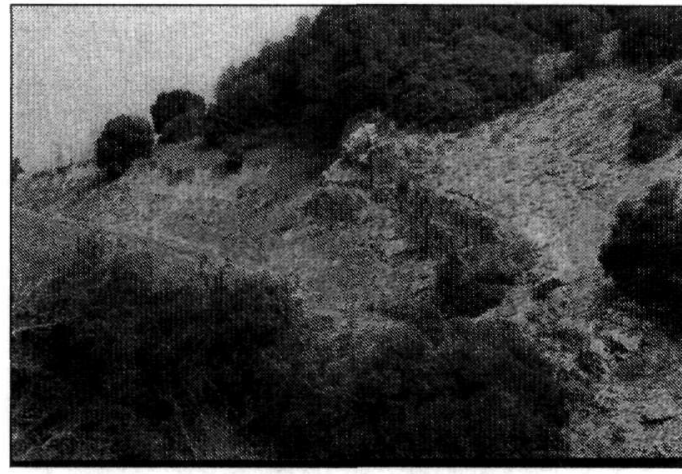

Figure 6. View of Sycorachi fault surface

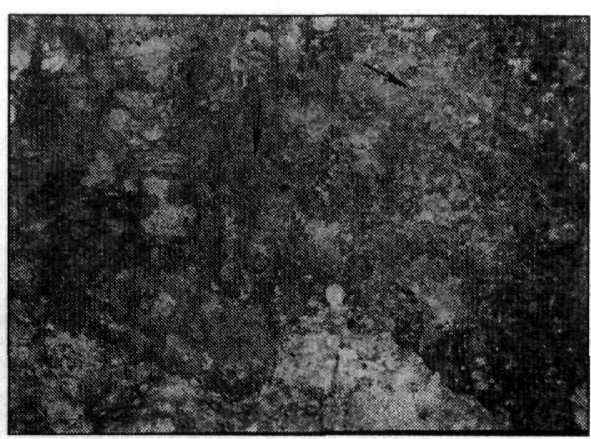

Figure 7. Detail of fault plane showing the two different tectonic striations (black arrows).

\subsection{Evros fault}

This normal fault of NE-SW general direction is oblique-slip, dipping to the east and having a total length of $11 \mathrm{~km}$. It forms the western limit of Evros river lowering and has affected mainly the volcanic rocks as well as the eocene, neogene and quaternary sediments. It presents wellpreserved polished planes and the slickensides formed on their iron-oxide cover correspond to the active stress field orientation. Another parallel fault, presenting the same geometrical and geodynamic characteristics, is observed in the vicinity of Feres village, with a total length of about $10 \mathrm{~km}$.

Moreover, a number of recent minor faults with lengths ranging from 3.5 to $8 \mathrm{~km}$ have been detected in the same region (fig. 8 ), affecting neogene and quaternary sediments even of medium to low cohesion.

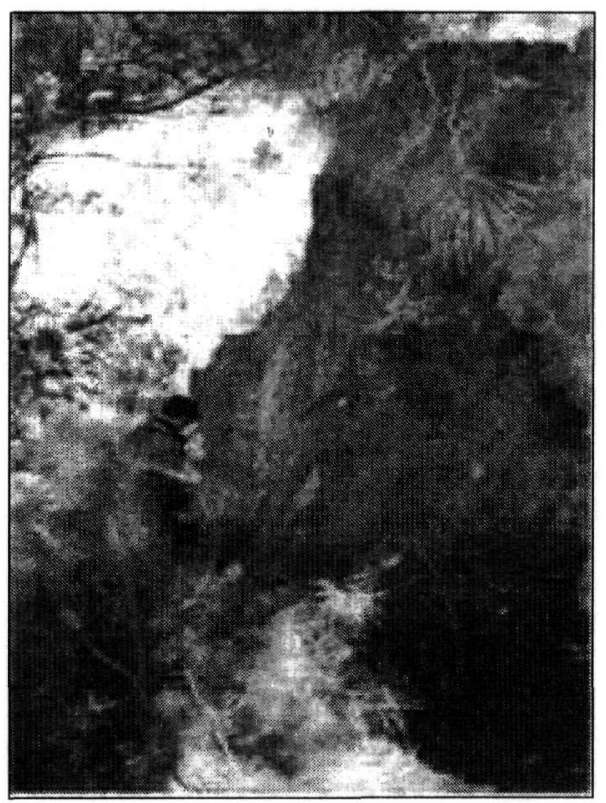

Figure 8. Fault plane with a NW-SW direction in Evros delta region.

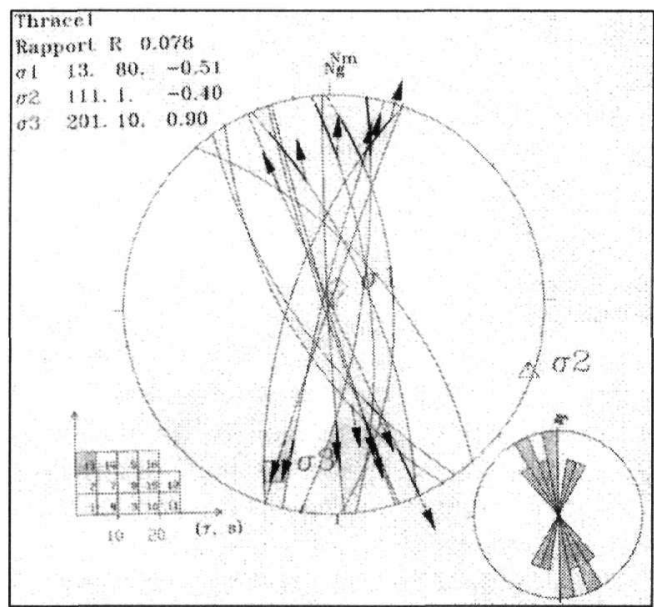

Figure 9. Stereographic projection of N-S fault planes with slickensides (thin arrows). The direction of the active stress field is shown by the $\sigma_{3}$ position. 
Based on the measurements of the most recent tectonic striations on the planes of about N-S directed faults in southern Thrace region a transtensional state of stress was confirmed with a NNESSW oriented $\sigma 3$ axis. These faults can be considered as sinistral second order faults, located in the zone between the major dextral faults that dominate in north Aegean.

Taking into account the existed empirical relationships connecting the seismic magnitude and the fault length with the seismic displacement (wells \& coppersmith, 1994), the experience related to the specific conditions prevailing over the Hellenic territory and the fact that the faults length ranges from 3.5 to $21 \mathrm{~km}$, it is estimated that the maximum expected seismic displacement varies from $10 \mathrm{~cm}$ to $70 \mathrm{~cm}$ respectively.

Since these faults have slip vectors inclined between $18^{\circ}$ and $28^{\circ}$, a significant proportion of the total displacement (about 70\%) must be expressed in the horizontal sense. Nevertheless, for a most accurate approach of the expected displacements, the implementation of a detailed study is considered necessary for each fault, co-evaluating also the behavior of the geological material.

\section{CONCLUDING REMARKS}

Eastern Macedonia and Southern Thrace areas have been affected by faults that have ENEWSW, WNW-ESE and about N-S (NNW-SSE and NNE-SSW) main directions. These major faults are very well observed on satellite images and aerial photos. Besides, field studies revealed the potential activity of the existed faults, even the low to moderate seismicity of this area. The most important structure is the Kavala-Xanthi-komotini fault with a total length of about $120 \mathrm{~km}$ which is composed of three main segments. The first, Kavala-Xanthi segment of NE-SW direction dips $30^{\circ}$ to $40^{\circ}$ to the southeast, while the E-W Xanthi-Komotini segment has a dip that ranges from $50^{\circ}$ to $70^{\circ}$. The most eastern Kavala-Aissimi segment is represented by a more complicated zone of subparallel smaller structures.

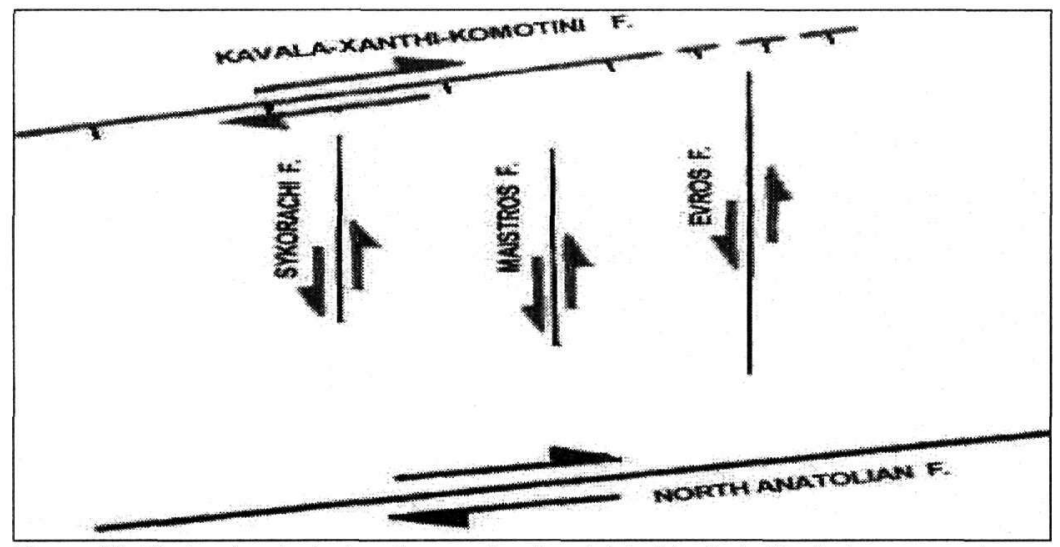

Figure 10. First order dextral and second order sinistral faults in North Aegean region.

In the area extended to the east of Komotini, the horizontal component of the movement dominates on oblique-slip to strike-slip faults of $\mathrm{N}$-S direction that present characteristic morphotecronic features of recent activity. They have a dip more than $60^{\circ}$ and slip vectors between $18^{\circ}$ to $28^{\circ}$ with a main sinistral movement. These faults could be considered as second order structures located and reactivated in the zone between the existed major dextral faults zones that dominate in North $\mathrm{Ae}$ gean, where an extentional component is also present

The recent faults of this area are controlled by the active transtensional stress field with $\sigma_{3}$ axis of NNE-SSW direction, as determined from the tectonic analysis of the faults, based on the tectonic striations measurements.

Based on the empirical relationships connecting the fault length with the seismic displacement, it is estimated that in case of reactivation of these faults during a strong earthquake, the maximum displacement along them varies between $10 \mathrm{~cm}$ and $70 \mathrm{~cm}$. Although the reactivation period 
seems to be long, after the historical and recent seismological data, a future seismic event related mainly to the North Anatolian Fault system earthquakes is possible.

\section{REFERENCES}

Carey-Gailhardis E. \& Mercier J. L., 1987: A numerical method for determining the state of stress using focal mechanisms of earthquake populations. Earth planet. Sci. Lett. 82, p.165-179.

Karfakis I., 1991.Application of remote sensing techniques in Geology and Mineral exploration of eastern Rhodope region (Northern Greece). Ph. D. Thesis, Patras Univ., p. 185.

Katsikatsos G., 1992: Geology of Greece, Athens.

Kiratzi A., 2002: Stress tensor inversions along the westernmost North Anatolian Fault Zone and its continuation into the North Aegean Sea. Geophys. J. Int. 151, p. 360-376.

Kiratzi A., Louvari E., 2003: Focal mechanisms of shallow earthquakes in the Aegean Sea and the surrounding lands determined by waveform modeling : a new database. Journal of Geodynamics 36, p. 251-274.

KockeL, F., Walther, H.W., 1965: Die Strimonlinie als Grenze zwischen Serbo-Mazedonischen und RilaRhodope-Massiv in Ost-Mazedonien. Geol. Jb., 83, 575-602, Hannover.

Kopp, K.O., 1965: Geologie Trhakiens II: Das Tertiar zwischen Rhodope und evros. Ann. Geol. Pays hellen., 46, 315

Koukouvelas, I.K. and Aydin A., 2002. Fault structure and related basins of the North Aegean Sea and its surroundings. Tectonics, 21(5), 1046.

Kronberg, P., Meyer, W., Pilger, A., 1970: Geologie der Rila-Rhodope-Masse zwischen Strimon und Nestos (Nordgriechenland). Beih. Geol. Jb., 88, p. 133-180, Hannover.

Lalechos N., Savoyat Ed., 1979: La sédimentation néogène dans le fossé nord-égéen. VI Coll. On the Geology of the Aegean region, vol. II, p. 591-603.

Maratos G., Andronopoulos V., 1965: The fauna of limestones of Aliki-Alexandroupolis, (Rhodope phyllites). Bull. Geol. Soc. Grercr, 6 (2), 348-352 (in Greek).

Mercier J., Sorel D., Simeakis K., 1987: Changes in the state of stress in the overriding plate of a subduction zone: the Aegean Arc from the Pliocene to the Present. Annales tectonicae. Vol. 1, No 1, 20-39.

Mouyiaris N., 1994: The seismic History of the Aegean land (from 2400 B.C. to 1990 A.D). Ph.D. Thesis. P. 440, Univ. of Patras.

Papadopoulos P., 1980: Geological Map of Greece scale 1:50.000, sheet Ferai-Peplos-Ainos. I.G.M.E. Athens.

Papazachos, B.C. \& Papazachou, C., 199): The earthquakes of Greece. Ziti Ed Thessaloniki.

Papadakis L. \& Galanakis D., 1991: Correlation of active/seismic faults with the main route and branches of natural gas pipeline. Main Part Neotectonic study. D.E.P.ALASPROFOS. Athens.

Pavlides S., Mountrakis D., KIlias A., Tranos M., 1990: The role of strike-slip movements in the extensional area of Northern Aegean (Greece). A case of transtensional tectonics. Annales Tectonicae. Special Issue Vol. IV n.2, p. 196-211.

Roussos N., Lyssimachou TR., 1991: Structure of the Central North Aegean Trough: an active strike-slip deformation zone. Basin Research 3, 39-48.

Wells D. \& Coppersmith ,1994. New empirical relationships among magnitude, rupture length, rupture area and surface displacement. Bull. Seism. Soc. Amer., vol. 84, No 4, pp.974-1002. 